\title{
Physical activity as an indicator of predictive functional disability in elderly ${ }^{1}$
}

\author{
Jair Sindra Virtuoso Júnior ${ }^{2}$ \\ Sheilla Tribess ${ }^{3}$ \\ Thais Reis Silva De Paulo ${ }^{4}$ \\ Cristiane Alves Martins ${ }^{4}$ \\ Vicente Romo-Perez ${ }^{5}$
}

\begin{abstract}
To analyze the time spent on physical activity in female and male individuals as a predictor of the absence of functional disability in older adults, a cross-sectional study was conducted with 624 individuals. Receiver Operating Characteristic curves (ROC) were constructed and compared to areas of physical activity by gender and the absence of functional disability. We identified cutoffs of physical activity (minutes / week) to predict the absence of functional disability (CI 95\%). It was found that there is a higher area under the ROC curve for the time spent on physical activities in females. It was observed that 280 minutes / week (women) or 410 minutes / week (men) were the best cutoff points for predicting the absence of functional disability. Time spent on physical activity practices can serve as an important indicator to sort priority groups for certain interventions.

Descriptors: Disabled Persons; Geriatric Nursing; Aged.
\end{abstract}

\footnotetext{
${ }^{1}$ Supported by Fundação de Amparo à Pesquisa do Estado de Minas Gerais (FAPEMIG), process \# APQ-03000-10.

2 PhD, Adjunct Professor, Universidade Federal do Triângulo Mineiro, Brazil.

${ }^{3}$ Doctoral student, Universidade de Brasília, Brazil.

${ }^{4}$ Master's student, Universidade Federal do Triângulo Mineiro, Brazil.

${ }^{5} \mathrm{PhD}$, Associate Professor, Universidad de Vigo, Spain.
}

Corresponding Author:

Jair Sindra Virtuoso Júnior

Rua Manoel Coelho, 199, Bloco 4, Apto. 403

Bairro: Olinda

CEP: 38055-600, Uberaba, MG, Brasil

E-mail: jair@ef.uftm.edu.br 


\section{Atividade física como indicador preditivo para incapacidade funcional em pessoas idosas}

Para analisar o tempo despendido em atividades físicas, nos sexos feminino e masculino, como preditor da ausência da incapacidade funcional em idosos, procedeu-se ao estudo transversal com 624 indivíduos. Foram construídas curvas Receiver Operating Characteristic (ROC) e comparadas às áreas de atividade física, por sexo e à ausência da incapacidade funcional. Identificaram-se pontos de corte de atividade física (minutos/ semana) para predizer a ausência de incapacidade funcional (IC 95\%). Encontrou-se maior área sob a curva ROC para o tempo despendido em atividades físicas no sexo feminino. Observou-se que 280 minutos/semana (mulheres) ou 410 minutos/semana (homens) foram os melhores pontos de corte para predizer a ausência de incapacidade funcional. O tempo despendido em práticas de atividades físicas pode servir como importante indicador para seleção de grupos prioritários, visando determinadas intervenções.

Descritores: Pessoas com Deficiência; Enfermagem Geriátrica; Idoso.

\section{Actividad física como indicador de incapacidad funcional predictivo en personas mayores}

Para analizar el tiempo que los hombres y mujeres invierten en actividad física, como un predictor de la ausencia de discapacidad funcional en las personas mayores, se llevó a cabo un estudio de corte transversal con 624 individuos. Se desarrollaron las curvas Receiver Operating Characteristic (ROC) y se compararon con las áreas de la actividad física, por sexo y la ausencia de discapacidad funcional. Se identificaron los puntos de corte de la actividad física (minutos/semana) para predecir la ausencia de discapacidad funcional (IC 95\%). Se encontró un área mayor bajo la curva ROC para el tiempo que invierten las mujeres en actividad física. Los resultado sugieren, que 280 minutos/semana (en mujeres) y 410 minutos/semana (en hombres), son los puntos de corte que mejor predicen la ausencia de discapacidad funcional. El tiempo invertido en realizar actividad física, se puede utilizar como un importante indicador para realizar la clasificación de los grupos prioritarios en ciertas intervenciones.

Descriptores: Personas con Discapacidad; Enfermería Geriátrica; Ancianos.

\section{Introduction}

The benefits of physical activity for people's health have been well documented in different clinical experimental studies ${ }^{(1)}$ and epidemiological surveys ${ }^{(2-3)}$. As physical activity behavior represents an essential theme for public policies in health, the monitoring of physical activity levels has been increasingly common in recent years ${ }^{(4)}$.

The importance of physical activity in people's lives stands out, independently of the age range. In the elderly population, concern has been growing due to its high and increasing prevalence in the Brazilian population, as well as that of the aging process accompanied by physical decline, which can be minimized through physical activity(5).
Current recommendations establish 150 minutes per week of moderate or intense physical activity ${ }^{(6)}$. Although this recommendation is modest and refers to the minimum quantity people should accomplish in one week, prevalence studies demonstrate that a very small part of the elderly population reaches this target(7-8).

Physical inactivity contributes to the development of degenerative chronic conditions and maximizes the decline process of physical functions, which entails the establishment of disabling processes ${ }^{(9)}$. Functional disability is something prevalent in the elderly population and remits to dependence in the accomplishment of daily activities ${ }^{(10)}$. 
Functional disability represents the limitation in the performance of socially defined roles and tasks within a sociocultural environment. Functional disability, in turn, precedes functional limitations and receives influence from genetic and environmental aspects, diseases and the level of physical activity ${ }^{(11-12)}$

Functional ability can be classified in three layers ${ }^{(13)}$ : the first refers to Advanced Activities of Daily Living (AADL), is related to the functions needed to live alone, specific for each individual and includes the occupational and recreational functions and service delivery; the second layer refers to Intermediary Activities of Daily Living (IADL), which include essential tasks to maintain independence; and, finally, Basic Activities of Daily Living (BADL), which comprise self-care activities.

When considering the American Geriatrics Society's(13) layering of hierarchical domains for functional ability, it is easy to understand the importance of keeping up physical activity, whether to maintain and expand social networks or even job activities.

Despite the existence of cutoffs of physical activity ${ }^{(6,14)}$, these indicators do not remit to disabling process for the elderly. Also, specific information is needed on population subgroups in different Brazilian regions. Knowledge about the minimum duration of physical activity needed to preserve functional capacity can be used to support other public health strategies aimed at improving elderly people's functional condition and wellbeing.

This study aimed to analyze the predictive power and to identify the cutoffs of physical activity for the absence of functional disability in male and female elderly.

\section{Methods}

A cross-sectional study was developed in Uberaba, located at $494 \mathrm{~km}$ from Belo Horizonte, the state capital of Minas Gerais, in the Brazilian Southeast, between May and August 2010.

The sample comprised 624 people aged 60 years or older, obtained through a random home-based selection and representing the urban region of the city. A proportional sample in terms of District, Family Health Team and gender was used. These elderly showed no severe visual and hearing acuity difficulties, did not use wheelchairs, were not temporarily or definitively bedridden and were not suffering any severe sequelae of cerebrovascular accident (CVA) with localized strength loss, nor any terminal disease.

The procedures for finite populations were used to determine the sample $\operatorname{size}^{(15)}$. In this calculation, significance was set at $5 \%$ (corresponding to a $95 \%$ confidence interval, $z[a] / 2=1.96$ ) and a tolerable sampling error of $3 \%$, resulting in a necessary sample of 490 subjects. This first sampling size estimate was increased by $20 \%$ to explore adjusted associations among the analyzed components, besides $10 \%$ to compensate for occasional losses, totaling a minimum necessary sample of 588 elderly.

For assessment purposes, a multidimensional interview was elaborated, applied individually, comprising questions related to socio-demographic aspects: age, education, marital status, job activity, family size and economic class(16); physical and mental health aspects: morbidities and cognitive function (Mini-Mental State Examination)(17); behavioral aspects: habitual physical exercise $^{(18)}$

The habitual physical exercise level was obtained through the International Physical Activity Questionnaire (IPAQ), adapted for the elderly ${ }^{(18)}$, which presents examples of common activities for elderly people. The instrument also contains a field with information about time records, considering the hours and minutes normally used each day of the week, instead of merely indicating the weekly frequency and total time during which these activities were done.

The IPAQ contains questions related to physical activities in a common week, of moderate and or strong intensity, with a minimum duration of 10 continuous minutes, distributed across five physical activity domains: work, transportation, housework, leisure/ recreation and sitting time.

Functional disability was measured according to the instrumental activities of daily living (IADL), using the adapted version of Lawton's Index ${ }^{(19)}$. Thirteen points was adopted as the cutoff for the presence of dependence.

The variables were characterized as means, standard deviation, minimum and maximum values and frequencies. The Kolmogorov-Smirnov test was applied to test the normality of the functional disability, physical activity, cognitive function coefficients, and also of the socio-demographic indicators. To compare the variables according to gender, Student's t-test for independent samples (continuous data) and the Chi-square test were used (categorical data).

The predictive power and cutoffs in the age period (age), in both genders, for the absence of functional ability, were identified through the Receiver Operating Characteristic (ROC) curves, frequently used to determine cutoffs in diagnostic or screening tests ${ }^{(20)}$.

Initially, the total area under the ROC curve was identified for physical activities in female and male 
individuals for the absence of physical disability. The greater the area under the ROC curve, the greater the discriminatory power of physical exercise for the absence of functional disability. A 95\% confidence interval (CI) was used, which determines whether the predictive capacity of physical activity standards in their different domains is not random, with a minimum inferior limit of $0.50^{(21)}$.

Next, sensitivity and specificity were calculated, besides cutoffs for total physical activity without functional disability. Values identified through the ROC curve constitute cutoffs that should enhance a more adequate balance between sensitivity and specificity for physical activity as a discriminator of absence of functional disability. Data were analyzed using statistical software MedCal version11.4.4.

This research followed the ethical principles present in the Helsinki Declaration and in National Health Council Resolution No. 196/96. The research protocols were assessed and approval was obtained from the Research Ethics Committee at Universidade Federal do Triângulo Mineiro (Opinion No. 1521/2009).

\section{Results}

The study population's mean age was 71.08 years $(S D=7.77)$, ranging between 60 and 96 years. In general, elderly who were married or lived with a partner $(52.7 \%)$ predominated, who lived in multigenerational homes (54.8\%), with a low education level, as $89.1 \%$ had not finished primary education. As for the job situation, $81.5 \%$ of the elderly were retired or pensioners belonging to economic classes " $C$ " (51.4\%) and "D" (33.2\%), that is, a low economic classification.

The distributions of the age, body mass, stature, years of education, physical activity, cognitive function and functional disability variables of the 624 elderly who participated in this study are displayed in Tables 1 and 2 .

Table 1 - Mean and standard deviation of sociodemographic, anthropometric and behavioral variables analyzed in this study. Uberaba, MG, Brazil, 2010

\begin{tabular}{|c|c|c|c|c|c|}
\hline \multirow{2}{*}{ Variable } & \multicolumn{2}{|c|}{ Female $(n=406)$} & \multicolumn{2}{|c|}{ Male $(n=218)$} & \multirow{2}{*}{$\mathbf{P}$} \\
\hline & Mean & SD & Mean & SD & \\
\hline Age (years) & 70.80 & 7.95 & 71.60 & 7.40 & $0.43^{*}$ \\
\hline $\begin{array}{l}\text { Education (years of } \\
\text { study) }\end{array}$ & 1.39 & 1.05 & 1.51 & 1.14 & $0.07^{*}$ \\
\hline Body Mass (kg) & 65.75 & 14.74 & 72.51 & 14.20 & $0.41^{*}$ \\
\hline Stature (cm) & 153.17 & 6.36 & 165.13 & $\begin{array}{l}7.03 \\
\text { (con }\end{array}$ & $\begin{array}{l}0.26^{*} \\
\text { nue... }\end{array}$ \\
\hline
\end{tabular}

Table 1 - (continuation)

\begin{tabular}{|c|c|c|c|c|c|}
\hline \multirow{2}{*}{ Variable } & \multicolumn{2}{|c|}{ Female $(n=406)$} & \multicolumn{2}{|c|}{ Male $(n=218)$} & \multirow{2}{*}{$\mathbf{P}$} \\
\hline & Mean & SD & Mean & SD & \\
\hline \multicolumn{6}{|c|}{ Physical Exercise (min/week) } \\
\hline Work & 23.24 & 123.22 & 64.40 & 221.60 & $0.00^{*}$ \\
\hline Transportation & 60.37 & 70.42 & 77.94 & 95.38 & $0.00^{*}$ \\
\hline Housework & 171.87 & 166.81 & 54.29 & 90.43 & $0.00^{*}$ \\
\hline $\begin{array}{l}\text { Leisure/ } \\
\text { recreation }\end{array}$ & 54.37 & 94.39 & 73.76 & 121.11 & $0.00^{*}$ \\
\hline Total & 308.03 & 271.97 & 270.39 & 297.63 & $0.96^{*}$ \\
\hline
\end{tabular}

*value obtained through Student's t-test for independent samples; Total Physical Activity = sum of work, transportation, home and leisure domains.

Table 2 - Frequencies and percentages for cognitive function and functional disability variables analyzed in the study. Uberaba, MG, Brazil, 2010

\begin{tabular}{|c|c|c|c|c|c|}
\hline \multirow{2}{*}{ Variable } & \multicolumn{2}{|c|}{$\begin{array}{l}\text { Female } \\
(n=406)\end{array}$} & \multicolumn{2}{|c|}{$\begin{array}{c}\text { Male } \\
(n=218)\end{array}$} & \multirow{2}{*}{$\mathbf{p}$} \\
\hline & $\%$ & $\mathbf{N}$ & $\%$ & $\mathbf{N}$ & \\
\hline \multicolumn{6}{|l|}{ Cognitive Function } \\
\hline No alterations & 82 & 333 & 85.3 & 186 & \multirow{2}{*}{$0.29^{*}$} \\
\hline Mild to moderate alterations & 18 & 73 & 14.7 & 32 & \\
\hline \multicolumn{6}{|l|}{ Functional Disability (IADL) } \\
\hline Presence & 81.3 & 330 & 84.9 & 185 & \multirow{2}{*}{$0.26^{\star}$} \\
\hline Absence & 18.7 & 76 & 15.1 & 330 & \\
\hline
\end{tabular}

*value obtained through the Chi-square test

Despite the differences in means and frequencies between males and females for the variables under analysis, only the physical activity domains showed significant differences. Women spent less time (minutes/ week) on work, transportation and leisure, against the long time spend on housework when compared with men.

The presence of mild to moderate cognitive alterations was perceived in $14.7 \%$ of the interviewed elderly men and $18 \%$ of the women, without significant differences. Likewise, functional disability for instrumental activities of daily living showed similar frequencies among men and women.

ROC curves were constructed for men and women (Figures 1 and 2). The areas under the ROC curves and their respective confidence intervals were observed for the time spend on physical exercise as a predictor of the absence of functional disability, with a greater area for women.

Picture 1 displays the cutoff, with the respective sensitivity and specificity levels, for physical activity (minutes/week) as a predictor of absence of functional disability in elderly women. The cutoff determined for physical activity was 280 minutes/week, with a $78.4 \%$ sensitivity and $64.0 \%$ specificity level. 


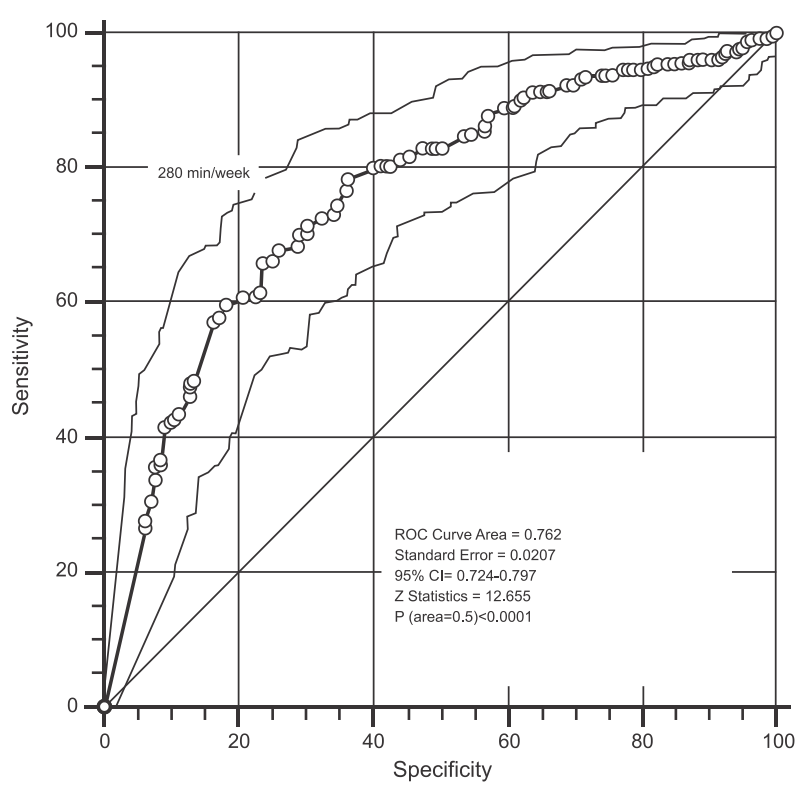

Figure 1 - Area under the ROC curve, with cutoff for time spent on physical activity as a predictor for absence of functional disability in elderly women

Figure 2 refers to elderly men, for whom the cutoff for the time spent on physical activity amounted to 410 minutes/week ( $85.5 \%$ sensitivity and $37.9 \%$ specificity).

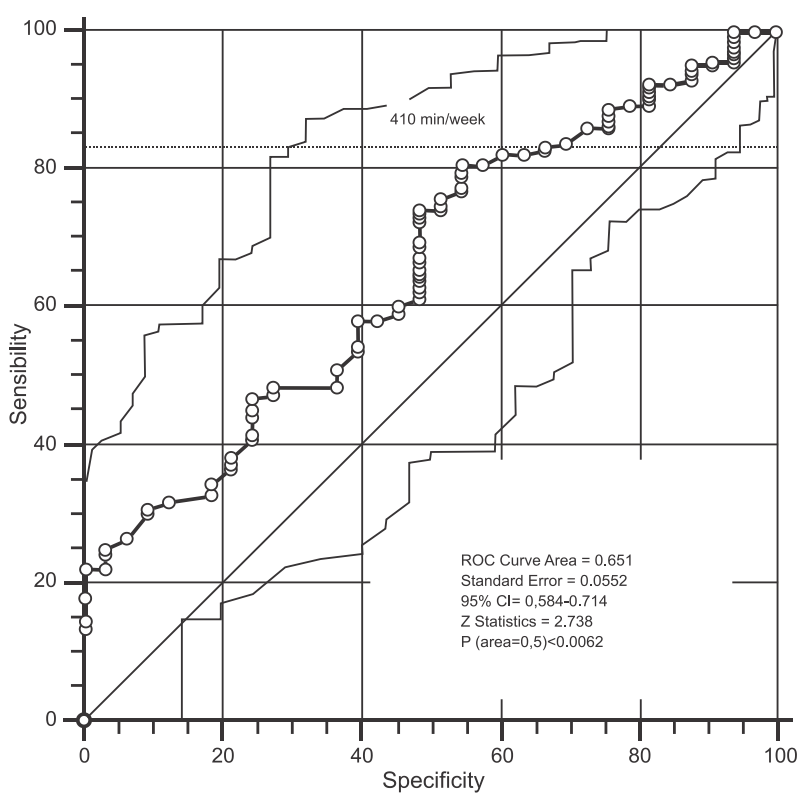

Figure 2 - Area under the ROC curve, with cutoff for time spent on physical activity as a predictor for absence of functional disability in elderly men

\section{Discussion}

Functional ability reflects the condition of independence for the accomplishment of daily activities.
In general, the decline in functional ability is more present as chronological age advances, in which aging processes interfere in elderly people's physical and mental health conditions ${ }^{(10,22)}$.

The diagnosis of functional ability and factors associated with functional disability permits the elaboration of effective strategies to promote people's health and wellbeing, as it anticipates elderly people's condition of chronic dependence ${ }^{(13-23)}$. The establishment of cutoffs for physical activity permits the early diagnosis of functional condition, still in the first stage of dependence, when it is easier to take preventive measures that impede the progression to the other stages of functional dependence.

When we analyze the distribution of the time spent on physical exercise, no differences can be identified in the total time spent on physical exercise. Women, however, use more time on physical activities in the domestic domain. Men show lower values and more time spent in the transportation and leisure domains. Cultural conditions can partially explain these differences, as women spend most of their time taking care of the home and men are impaired by the decline in social activities after retirement ${ }^{(24)}$.

According to the analyses, one can understand that the greater proportion of dependent elderly for Intermediary Activities of Daily Living, or Instrumental Activities of Daily Living (IADL) in the adopted classification $^{(23)}$ were men. The greater level of energy spent is positive in any physical activity domain but, in general, domestic physical activities are less values in relation to sociocultural and motivational components. These components are related with feelings of wellbeing, the presence of social networks and their action is positively associated with mental health(22)

The total physical activity cutoffs in the prediction of functional disability found in the study are higher than the physical activity parameters recommended for health(6). Nevertheless, the time spend on physical exercise to avoid functional impairments is lesser for women.

Gender differences can be explained by the more accelerated change in physical activity behaviors among male elderly as age advances(25). After retirement, besides the decrease in activity levels, social networks are considerably reduced, as opposed to women, whose changes due to aging seem to happen in a milder way.

Some limitations were found in this study: 1) the cross-sectional design hampers advances in temporal analyses of the factors studies, due to the reverse causality bias, so that no relation of causality could be 
identified; 2) Questionnaire use (measure of functional disability and habitual physical exercise level through a construct) can underestimate or overestimate some of the information found; 3) The different research instruments and parameters used to classify the elderly's functional ability and physical activity, beyond the cutoffs, make it difficult to compare the results with those of other studies.

On the other hand, the possibility of a selection bias in the study is limited, as a sample was used of elderly linked with Family Health Teams in Uberaba. Besides, cross-sectional and epidemiological studies are important for the development of public policies, as they provide instantaneous information on the reality of the population group that is being observed.

\section{Conclusions}

The behavior of physical activity practices can predict the absence of functional disability in male and female elderly. Elderly men need more physical exercise (410 minutes/week) than women (280 minutes/week) to achieve protective effects for disabling processes, despite the greater time spent on transportation, work and leisure. Women probably managed to reach a minimum physical activity time in those domains where men were superior. In the domestic activity domain, however, women's mean time was three times higher. These activities require high cognitive demands in the administration of daily activities.

The indicators of physical activity time to predict functional conditions entail clinical implications for elderly health, as insufficient physical activity levels can predict functional disability.

\section{References}

1. Ferreira SR, Gimeno SG, Hirai AT, Harima $H$, Matsumura L, Pittio BA. Effects of an intervention in eating habits and physical activity in Japanese-Brazilian women with a high prevalence of metabolic syndrome in Bauru, São Paulo State, Brazil. Cad Saude Publica. 2008;24(2):294-302.

2. Hrobonova E, Breeze E, Fletcher AE. Higher Levels and Intensity of Physical Activity Are Associated with Reduced Mortality among Community Dwelling Older People. J Aging Res. 2011;7:1-10.

3. Paganini-Hill A, Kawas $\mathrm{CH}$, Corrada MM. Activities and mortality in the elderly: the leisure world cohort study. J Gerontol A Biol Sci Med Sci. 2011;66(5):559-67.
4. Florindo AA, Hallal PC, Moura EC, Malta DC. Practice of physical activities and associated factors in adults, Brazil, 2006. Rev Saúde Publica. 2009;43(2):65-73.

5. Gragno-Lati $M$, Jorgensen $\mathrm{OH}$, Rocha $\mathrm{R}$, Fruttero $A$. Envelhecendo em um Brasil mais Velho: Implicações do envelhecimento populacional sobre crescimento econômico, redução da pobreza, finanças públicas e a prestação de serviços. Washington: Banco Mundial LAC; 2011.

6. Haskell WL, Lee IM, Pate RR, Powell KE, Blair SN, Franklin BA, Macera CA, Heath GW, Thompson PD, Bauman A. Physical activity and public health: updated recommendation for adults from the American College of Sports Medicine and the American Heart Association. Med Sci Sports Exerc. 2007;39(8):1423-34.

7. Tribess S, Virtuoso-Júnior JS, Petroski EL. Fatores associados à inatividade física em mulheres idosas em comunidades de baixa renda. Rev Salud Pública. 2009;11(1):39-49.

8. Knuth AG, Bacchieri G, Victora CG, Hallal PC. Changes in physical activity among Brazilian adults over a 5-year period. J Epidemiol Commun Health. 2010;64(7):591-5. 9. Virtuoso-Júnior JS, Guerra RO. Fatores associados às limitações funcionais em idosas de baixa renda. Rev Assoc Med Bras. 2008;54(5):430-5.

10. Aires M, Paskulin MG, Morais EP. Functional capacity of elderly: comparative study in three regions of Rio Grande do Sul. Rev. Latino-Am. Enfermagem. 2010;18(1):11-7.

11. Lawrence $\mathrm{RH}$, Jette $\mathrm{AM}$. Disentangling the disablement process. J Gerontol B Psychol Sci Soc Sci. 1994;51:173-82.

12. Morey MC, Pieper CF, Cornoni-Huntley J. Physical fitness and functional limitations in community-dwelling older adults. Med Sci Sports Exerc. 1998;30:715-23.

13. American Geriatric Society. Assessment in Geriatrics. J Am Geriatric Soc. 1989;37:570-2.

14. Blair SN, LaMonte MJ, Nichaman MZ. The evolution of physical activity recommendations: how much is enough? Am J Clin Nutr. 2004;79(5):913-20.

15. Luiz RR, Magnanini MF. A lógica da determinação do tamanho da amostra em investigações epidemiológicas. Cad Saúde Coletiva. 2000;8:9-28.

16. ABEP. Associação Brasileira de Empresas de Pesquisa. Critério de Classificação Econômica Brasil 2008. [acesso 10 mar 2010]. Disponível em: http://www.abep.org/ novo/CMS/Utils/FileGenerate.ashx?id=13

17. Almeida OP. Mini exame do estado mental e o diagnóstico de demência no Brasil. Arq Neuropsiquiatr. 1998;56(3-B):605-12. 
18. Benedetti TRB, Mazo GZ, Barros MVG. Aplicação do questionário internacional de atividades físicas (IPAQ) para avaliação do nível de atividades físicas de mulheres idosas: validade concorrente e reprodutibilidade testereteste. Rev Bras Ciên Mov. 2004;12(1):25-34.

19. Santos RL, Virtuoso-Júnior JS. Confiabilidade da versão brasileira da escala de atividades instrumentais da vida diária. RBPS. 2008;21(4):290-6.

20. Erdreich LS, Lee ET. Use of relative operating characteristics analysis in epidemiology: a method for dealing with subjective judgment. Am J Epidemiol. 1981;114(5):649-62.

21. Schisterman EF, Faraggi D, Reiser B, Trevisan M. Statistical inference for the area under the receiver operating characteristic curve in the presence of random measurement error. Am J Epidemiol. 2001;154(2):174-9. 22. Rocha SV, Almeida MMG, Araújo TM, Virtuoso-Júnior JS. Prevalência de transtornos mentais comuns entre residentes em áreas urbanas de Feira de Santana, Bahia. Rev Bras Epidemiol. 2010;13(4):630-40.

23. Phillips W, Haskell W. "Muscular fitness" - Easing the burden of disability for elderly adults. J Aging Phys Activity. 1995;3:261-89.

24. Del Duca GF, Thumé E, Hallal PC. Prevalência e fatores associados ao cuidado domiciliar a idosos. Rev Saude Publica. 2011;45(1):113-20.

25. Benedetti TRB, Borges LJ, Petroski EL, Gonçalves LHT. Atividade física e estado de saúde mental de idosos.

Rev Saude Pública. 2008;42(2):302-7. 